\title{
Care for Nurses Only? Medicine and the Perceiving Eye
}

\author{
Elin Håkonsen Martinsen
}

Published online: 7 December 2010

(C) The Author(s) 2010. This article is published with open access at Springerlink.com

\begin{abstract}
In this paper I introduce a theoretical framework on care developed by the Norwegian nurse and philosopher Kari Martinsen, and I argue that this approach has relevance not only within nursing, but also within clinical medicine. I try to substantiate this claim by analysing some of the key concepts in this approach, and I illustrate the potential clinical relevance of this approach by applying it in relation to two care scenarios. Finally, I discuss some of the concerns that have been raised in relation to the aim of highlighting care in medicine.
\end{abstract}

Keywords Care - Doctor-patient relationship - Ethics of care $\cdot$ Kari Martinsen · Medical ethics · Nursing ethics

\section{Introduction}

Most of us agree that the assumption that "nurses care" and "doctors cure" is too simplistic, and that it is not uncommon for many nurses not to care very much at all, and for some doctors to care a great deal. However, in spite of this, there still is a theoretical discrepancy between nursing and medicine in relation to how care is handled; while care may be said to constitute an important part of professional selfunderstanding in nursing ${ }^{1}[7,27,28,38,39]$, it still may be said to be situated in the margins of the ethical thinking in medicine [9, 42, 51, 52], and seldom applied to

\footnotetext{
${ }^{1}$ However, this does not mean that there is agreement on how care is to be understood in relation to nursing. On the contrary, the concept of care in nursing may be understood in different ways and relates to different theoretical traditions.
}

E. H. Martinsen ( $₫)$

Section for Medical Ethics, Institute of Health and Society, Faculty of Medicine,

University of Oslo, PO BOX 1130 Blindern, 0318 Oslo, Norway

e-mail: e.h.martinsen@medisin.uio.no 
medical education [8]. Nursing and the nursing profession may be criticized for monopolizing the concept of care [49].

In light of this theoretical discrepancy and the fact that many patients complain about a lack of care when meeting with their doctors, and experiencing ignorance, insensitivity or degrading behaviour [24, 26, 35], this urges a further analysis of the relevance of the care discourse in medicine. Implementing nursing care perspectives in medicine is controversial for a number of reasons, and may be why it has not been explored thoroughly. However, this is not a reason to avoid the topic. On the contrary, there may be powerful perspectives that have not been considered because of prejudice.

Therefore, in this paper I attempt to bring some of this knowledge from nursing into the field of medicine, taking the influential scholarly works on care by Norwegian nursing scientist and philosopher Kari Martinsen as my point of departure. ${ }^{2}$ Kari Martinsen's work has influenced the current understanding of care in nursing in Scandinavian countries, and she belongs to a different theoretical tradition than the Gilligan's Anglo-American. Investigating Martinsen in the context of medicine will be interesting because it will represent an attempt to bridge the gap between related research traditions in medicine and nursing, and it will represent an attempt to relate the Scandinavian nursing debate on care inspired by phenomenology to the Anglo-American tradition of care ethics.

Interestingly, Søren Holm asks a similar question in his article, "What should other healthcare professions learn from nursing ethics?" [21]. However, Holm and I reach different conclusions: while Holm rejects the influence and importance of ethics of care in relation to nursing ethics and health care ethics in general, ${ }^{3}$ I welcome these perspectives, also in medicine.

In this paper I focus my attention on Martinsen's analysis of the different clinical gazes [41], and I will explore how this perspective may represent a prolific approach towards care in medicine. Care, by definition, "requires the recognition of a need" [57], so focusing on the way physicians see may represent an advantageous way of approaching care in medicine. The dominating gaze in medicine, however, is often referred to as powerful, objectifying and dehumanizing [14, 22, 24]. Therefore, I argue with Kari Martinsen that medicine needs to encourage and develop a "perceiving eye" [41]. The fostering of such an eye, or gaze, ${ }^{4}$ may facilitate care in each medical encounter, as well as refining clinical proficiency. In support of this claim, I first draw on some of the main features in Martinsen's care theory, trying to make her thinking comprehensible for readers outside Nordic countries as well. Subsequently, I analyse Martinsen's essay Seeing with the Heart's Eye, focusing on

\footnotetext{
${ }^{2}$ Even though Kari Martinsen's point of departure is the philosophy of nursing, her analysis focuses more on the relationship between the patient and health care professional in general than on the particular relationship between patient and nurse. Therefore I find her analyses also relevant in relation to medicine.

${ }^{3}$ Holm concludes that other healthcare ethics should learn from the resistance of nursing ethics to analytic reductionism, however, he does not ascribe this resistance to influences from an ethics of care [21]. Instead, he points to other theoretical positions such as some feminist ethicists (however, not the feminist ethicists dealing with care) and modern particularists emphasizing the situational importance of ethical decision making, as well as influences from various schools of continental philosophy.

4 I use the terms 'eye' and 'gaze' interchangeably throughout in the text.
} 
her analysis of what seeing means in health care (ibid.). By using examples, I aim to illustrate how the development of a sensous and perceiving eye in medicine may be of ethical as well as epistemological importance for the clinical encounter. Finally, I will discuss different objections to focusing on care in medicine, in relation to the perspective developed above.

\section{Kari Martinsen's Philosophy of Caring}

Influenced by phenomenology and the historic roots of caring in nursing, Kari Martinsen has approached the concept of care through different levels of analysis. I rely for the most part in this paper on her later works in which she "is thinking with," to use her own expression, the Danish philosopher and theologian Knud E. Løgstrup by analysing care phenomenologically [39-41].

Martinsen emphasizes care as being basic to human existence. She argues that as human beings we are basically social and dependent on other people and relies here on Løgstrup's view of human life as a life in interdependence ${ }^{5}$ [39, 40]. The assumption that human beings are interconnected and dependent upon each other thus represents a central ontological feature of Martinsen's theory. Thus, care constitutes a fundamental precondition of our lives: As human beings, we are basically dependent, and this dependency requires a human response in the form of care.

Martinsen always interprets a situation of care as being contextual, emotionally laden and particularistic in nature: "Care is to be concrete and present in a relationship by our senses and our bodies. It is always to be in a movement away from ourselves and towards the other," she writes [36, p. 11]. Care is to relate to the other in an unconditional and spontaneous way as a response to the concrete situation of the other. Nevertheless, in order to accomplish this, we must be able to recognize his or her needs in the first place. Therefore, noticing the need to care may be conceived of as a basic element of care [57]. ${ }^{6}$ Similarly, Martinsen argues that in order to care for the patient, "we must both be able to see and express the [patient's] appeal for help in order to strengthen the [patient's] life courage in the suffering" [37, p. 9]. She thus highlights the importance of noticing the need to care (to see), at the same time as focusing on the importance of practical action in care (to express). She also indicates an important ethical implication: namely, the strengthening of a patient's life courage. Consequently, care is not only about being empathic or being emotionally attached. The essential element, however, is to be able to recognize the need of the other and to act accordingly. For that reason, practical action represents an important dimension in Martinsen's care approach, together with a relational and

\footnotetext{
5 Through phenomenological investigations, Løgstrup came up with some basic phenomena which govern human interaction, and in his later writings he calls these modes of reaction "spontaneous manifestations of life" or "spontaneous utterances of life." Løgstrup argues that phenomena such as trust, hope, compassion and the openness of speech are pre-cultural characteristics of our existence, and ontologically express the basic entanglement of individual human beings [29, 30].

${ }^{6}$ According to Tronto, the three other elements of care are: to take care of, care-giving and carereceiving [57].
} 
a moral dimension. Care is thus a trinity: "relational, practical and moral simultaneously" $[3,38]$.

\section{Perceiving and Recording}

A central feature of the care philosophy of Martinsen is her emphasis on perception in our interaction with others, as well as in clinical situations, and she considers perception to constitute an important part of clinical judgment. ${ }^{7}$ In the essay Seeing with the Heart's Eye Martinsen explores different dimensions of the clinician's gaze [41]. She starts by drawing a distinction between "perceiving" and "recording": "By recording is meant the putting of oneself in an outside position, classifying," she argues (p. 72). When we record, we systematize and differentiate, albeit within the frameworks of an already existing conceptual system. The recording eye is reductionistic and neutral; it may reduce living characteristics, such as a laughing face, to clinical signs, characteristics and marks. It is the eye of the disinterested observer, in which the other, as a person, may become indifferent to us. In her description of the recording eye, Martinsen is also inspired by and refers to Løgstrup's conception of the "eye of the epoch" [31] and to Michel Foucault's well-known analyses of "the classifying gaze" and "the examining gaze" in medicine [14].

In contrast the perceiving eye is characterized by openness towards the world, where sensation and emotions are working together, says Martinsen. The perceiving eye opens for "a seeing emotion," in which we are touched and emotionally involved before we understand the needs of the other. Martinsen refers in this connection to the story of the Good Samaritan: The Samaritan saw the half-dead stranger and "was moved with compassion" [55]. He did not record first; instead, he was struck, pained by the wounded stranger. Martinsen refers here to the Greek word in the text, esplanknistae, which is "a verb made from a noun, meaning something to do with guts, stomach, abdomen, in other words an incredible physical pain" (Johannes Møllehave, cited in [41]). He was "pained in the gut," meaning that "he saw with his whole body, which was touched" (p. 84). The Samaritan's understanding of the situation was thus led by his senses, by his sensuous and perceiving eye.

So, why does Martinsen bring the story of the Good Samaritan into an essay on seeing in health care ${ }^{8}$ The story illustrates how the perceiving eye may facilitate care. In the story, the priest, the Levite and the Samaritan all saw the half-dead man, although they saw him in different ways. Significantly, the way they saw him had a major impact on the way they acted: the well-established and theoretically educated men, the priest and the Levite, saw the half-dead man and passed him by. Did they

\footnotetext{
7 Here Martinsen is influenced by Løgstrup and his position of "phenomenology of creation." To be perceptive and open reflects thus the attitude of the phenomenology of creation, of being reticent and of receiving the other as a gift $[39,40]$.

8 The story of the Good Samaritan is regarded as an exemplary story in the Nordic tradition within care ethics and nursing ethics, and its intrinsic value of charity is also considered as part of the basic values in the Norwegian health care system [54, 48].
} 
not trust their eyes? Did they have recording eyes and not perceiving eyes? Was the ailing man recorded as a stranger and therefore not of their concern, based on theory and culture? The Samaritan, on the other hand, got within the "perceiving range of life" [41]. He did not record first; instead, he was struck, pained by the wounded stranger.

\section{What Gaze is at Work in Medicine?}

How can we further transfer these theoretical insights to medicine? What gaze is at work here? As physicians we are trained to create a thorough medical history and make a clinical examination in order to give a proper diagnosis. The process of interviewing and examining the patient operates within a fixed framework, and even though we are encouraged to ask open-ended questions, the medical interview follows a standard scheme, investigating the patient's heredity, social history, education, employment history, drug history, tobacco and alcohol consumption, home circumstances, and the history of the present complaint(s). Likewise, the physical examination of the patient operates within the same framework, leading us towards a possible diagnosis of the patient. This perspective is evident if we go to a recenty updated text book in clinical examination for medical students [13]: "The examination really begins from the moments you set eyes on the patient," Epstein et al. write (p. 20). "As the patient approaches you in the consulting or examination room, observe the posture, gait and character of the stride," and when making your initial acquaintance with the patient, "the grip of the handshake usually provides some useful information" (p. 20-21). Thus, the first step of the examination is the inspection, during which we initially try to create a general impression of the patient: does she look well, or not? Is there any striking physical abnormality? Then we inspect the patient more specifically in relation to our examination of the different body systems, looking for signs and stigmata before we continue with palpation and auscultation of the heart and lungs. The medical exploring gaze thus operates within a fixed framework by systematizing, differentiating and classifying the information from the patient within a fixed totality. At the same time, physicians aim at remaining "professional" in meetings with patients. We usually understand the word professional to mean "keeping sufficient distance, not being overly involved (restraining emotions) and being objective and a matter of fact in one's speech" [41]. In light of this, I will argue that the dominant gaze of medical practice is a recording gaze, focusing too heavily on diagnoses and diseases alone and leaving out the sensitive openness to the patient's particular situation. ${ }^{9}$ This is also underscored by recent empirical findings, pointing to how physicians actually "essentialise" the patients' stories by breaking them down into concrete complaints and categorising the symptoms into medical sense [1], as well as studies pointing to

\footnotetext{
${ }^{9}$ Even so, there are different attempts to include the patient's perspective to a greater extent into medical practice. Patient-centred medicine represents one example of such an approach, in which the importance of pursuing both the patient's and the physician's agenda is emphasized [4, 44]. The works on clinical empathy in medicine by Halpern $[15,16]$ represents another example, as well as the works of the Nordic general practitioners Malterud and Hollnagel [33, 34].
} 
how the professional gaze actually may lead to humiliation and shame on part of the patient [35]. A possible consequence of such a recording gaze in medicine may be that physicians do not always "trust their own eyes" when meeting with patients who suffer. Let me offer an example:

\section{Do We Not Trust Our Eyes?}

In an article in the Journal of the Norwegian Medical Association, Kristin Ribe, who has suffered for several years from self-injury and suicidal thoughts, describes her meeting with health personnel (first and foremost physicians) at the emergency ward, arriving with self-inflicted bleeding wounds again and again [53]. She describes anger or indifference by the doctors who meet her with expressions such as "Are you here again, pull yourself together!" or "Now you must stop being silly!" or "We can't use all our time on you. Don't you see how many people are in the waiting room?" "One doctor did not even say hello to me," she writes. "He just equipped himself and talked over an hour with the nurse about his cottage, while I was only something lying there, a scrap, a nothing" (ibid.).

It is tempting and may be relevant to draw a parallel here between the doctors' behaviour and that of the priest and the Levite in the story of the Good Samaritan. Like the priest and the Levite, these doctors might not believe their own eyes. A young woman arrives at the emergency unit with bleeding wounds, and they meet her with ignorance, blame or anger. Did they not believe their eyes? They probably saw her with a recording gaze, founded on their medical knowledge and the medical culture. Among many health professionals, there has been a widespread tendency to think and talk about self-injuring patients as manipulative [43]. Did the doctors record the patient as manipulative and therefore outside of their moral concern-just like the priest and the Levite, who recorded the injured man as a stranger and as someone they were not obliged to help, based on their culture and their laws?

The recording gaze is powerful in its objectification of the other. Through a recording eye, we may see a person as an object or a completed fact, and this may threaten the person's integrity. Integrity means that which must not be hurt, damaged or altered, but which should be respected and protected [23], and for a person who is seen as an object, it may be both painful and damaging. The selfinjuring girl precisely delineates the damaging effects of a recording eye when she says she felt like "a scrap, a nothing" when treated by the doctor who ignored her. Through this type of objectifying behaviour, the doctor threatened her integrity. As a consequence, we see how the recording activity of the professionally trained eye may be damaging to the patient. However, this kind of viewing of the patient is also necessary in order to understand the patient's medical condition and to reach a diagnosis. Thus, in order to care for the patient in a broader sense than just making a diagnosis and initiating treatment, we must strive to integrate and combine the two modes of seeing the patient: to see with openness and ease, such as seeing with the perceiving eye, while also seeing in an academic, exploring and evaluating way.

Besides the protection of patient integrity, Martinsen points to another important ethical implication of displaying a perceiving gaze in medicine, namely, the 
strengthening of patients' life courage. This aspect of the perceiving gaze is also illustrated in the article by Ribe, in which she describes physicians who actually saw her, receiving her appeal for help, rather than abandoning it. She describes the good in a physician who saw her scars and said: "I see you have had a difficult time," and she describes the positive potential in such a response from another person, as something that was "very good to feel" and to take with her when she returned outside again [53]. "I need the physician at the emergency ward, whose hands trembled while he was suturing," she writes. "For him I was not routine. My wound, my pain moved him. And that was very good to feel, to take with me outside" (ibid.).

\section{The Epistemic Potential of Care}

Care may also be epistemologically essential in the clinical encounter, and in the following example I try to illustrate how seeing patients with a perceiving eye also may contribute to refining the clinical abilities of the physician:

Earwax is the problem for the next patient on the list, and the doctor envisages a short consultation, hoping to catch up with some work that is behind. After examining the patient's ears, the physician confirms the diagnosis and orders the appropriate treatment. The consultation is over with in five minutes, and the patient is supposed to leave. The doctor knows the patient from previous consultations; he is a middle-aged man, well-ordered and with no medical history. Still, today the physician becomes aware that something is different. Maybe it is something in the way the patient walks, or talks that makes it difficult for the physician to end the consultation as planned. Maybe it is something in the patient's eyes that touches the physician, so that instead of turning to his computer, he asks the patient one more time how he is doing. "I do not sleep," the patient answers. "Well, for how long a time have you not been sleeping?" the physician asks. "Since I was twelve years old," answers the patient, who then he loses his well-ordered appearance and tells a history of many years of child abuse in his childhood home, terrorized by a violent father. The patient is upset and starts to cry, and the consultation turns into something quite different from the treatment of bilateral earwax.

As I see it, this example illustrates the epistemic potential in holding on to the concreteness in the situation by displaying the sensuous and perceiving eye instead of immediately starting a process of abstraction. The physician could have disciplined the situation by following his plan for an efficient consultation and doing a proper job treating the patient's earwax. And many physicians do end their consultations just like this. But an extra weight in the patient's steps or something in the patient's eyes moved the physician, and by being aware of his own "seeing emotions" in meeting with the patient, he captured some important information regarding the patient's clinical situation. This is important both in regard to the medical state of the patient, by initializing further examination and treatment of his insomnia, but also in relation to bringing forward the courage to live, as Martinsen expresses it. 


\section{To Care or Not to Care?}

So far, I have discussed central conceptions in the care philosophy of Kari Martinsen in relation to medicine, focusing on her discussion of seeing in health care and her conceptions of the perceiving and the recording eye. I have asserted that seeing in medicine is dominated by a recording gaze and that the development of a sensuous and perceiving gaze is important in order to facilitate care and refine clinical proficiency.

There are many aspects to discuss here, and I will not discuss Martinsen's theoretical perspective in this context more, ${ }^{10}$ but I will discuss the possible drawbacks of highlighting such a perspective in medicine. In this connection, it is important to point out that even though care has been a marginalized area of inquiry within the philosophy of medicine and medical ethics, there is an ongoing transition in the medical ethical landscape by which the feasibility of ethics of care in relation to medicine is being recognized within philosophy of medicine $[10,11,42,58]$, medical education [8], feminist ethics [56] and medical anthropology [25].

There are, of course, many worries that might be raised for a care orientation in the context of medicine and medical ethics. In the following section I will deal with some of the arguments related to the assertion that a care perspective in medicine will likely bring about bad consequences for patients and physicians. By this, I limit my discussion to exclude critical arguments trying to assert that the notion of care itself is problematic and unnecessary [2, 12, 19]. Let us look at some of the objections that are particularly germane to the present discussion:

First, it might be said that caring interferes with proper medical practice by inhibiting the doctor's organization of information, in addition to the decisionmaking process [32]. Beauchamp and Childress, discussing the virtue of compassion in medicine, point to this connection in how compassion "can blind reason and impartial reflection" [5]. "Constant contact with suffering can overwhelm and even paralyze a compassionate physician and nurse," they write (p. 40). In response to this worry, it is important to point out that there is nothing intrinsic to the care perspective that excludes appropriately detached forms of concern and compassion, to paraphrase Carse [9]. "A good health care professional should be able to summon the appropriate degree of emotional detachment, or equanimity, when this is crucial to serving the well-being of the patient," Carse argues (p. 23).

If we relate this objection to Martinsen's perspective, we may ask whether the display of a perceiving gaze in medicine may inhibit rather than facilitate medical practice. First, according to Martinsen, proper care is not concordant with actions that disrupt the necessary medical work. Here, I rely on her emphasis on professional reflection in relation to the clinical encounter. In Martinsen's view, clinical judgment depends on professional knowledge to structure and organize the

\footnotetext{
${ }^{10}$ Martinsen's perspective has been debated widely. She has been criticized for pursuing an altruistic notion of care $[18,50]$, and for emphasizing "samaritanism" as an ethical ideal in relation to the ethics of care [50], as well as for romanticizing nursing practice [17]. She has been criticized for toning down the importance of research and the need for scientific knowledge in nursing [46]. The use of Løgstrup's ethics and phenomenology as the main source for health care ethics also has been criticized [20]. A more substantial elaboration of this critique is found in my forthcoming $\mathrm{PhD}$ thesis.
} 
information, as well as an ability to be open and sensitive toward the patient. Because of this, comforting the patient instead of initiating proper medical treatment is not consistent with good care, but is more like what Martinsen denotes as sentimental care. According to Martinsen, sentimental care is care in which the caregiver's participation in the other person's suffering is limited to the caregiver's self-centred emotions [38]. When the caregiver confines him or herself to pitying the patient and refrains from helping the patient in a professional manner, the care becomes sentimental. Second, as we experienced in the example with the patient with earwax and insomnia, care may be epistemologically essential in the clinical encounter because caring attitudes and sensitivities may allow access to important knowledge about the patient's subjective experiences of illness, which may be crucial in acquiring a proper understanding of the patient's condition. ${ }^{11}$ Accordingly, from my point of view, the understanding of care as an inhibitor of medical practice may be due to an inadequate conception of care as well as a failure to recognize how care may contribute to refining clinical proficiency by being epistemologically relevant.

Second, it might be argued that caring for a patient may lead to difficulties for the physician with regard to causing the patient therapeutically necessary pain or breaking bad news to the patient [12]. As I see it, such a worry is based on an inadequate conception of care and I refer to Martinsen's conception of sentimental care; according to Martinsen, care is more than feeling sorry for, having a liking for, or being emotionally attached to someone. Care also involves a practical participation in the other person's suffering and concrete action based on professional judgement. Therefore, to leave out a painful but important procedure for the patient because of one's caring for that patient is not concordant with proper care.

Third, it might be said that there are important moral issues that may fall outside the reach of an ethics of care. One main worry is that an ethic of care will have nothing to say about certain forms of injustice [45]. Will physicians be inclined to favour their patients over other physicians' patients or the need of the community? In this regard it is important to point out that the partialistic feature of an ethic of care does not afflict the caring agent with "tunnel vision" [42]. This point is also evident in Martinsen's perspective that, besides emphasizing a spontaneous care response towards the other, mediated through a perceiving eye, also emphasizes the importance of professional judgment and reflection in the clinical encounter [39]. Accordingly, the professional may not have the opportunity to focus his or her attention on the care of one person or group of persons to the complete exclusion of the wants and needs of others. It is also important to point out that what is in question in the care perspective is not necessarily to question the importance of justice, but pointing to additional ways of moral reasoning [9]. Therefore, "an

\footnotetext{
11 The epistemic potential of care also is underscored by the conception of sensibility as explicated by Nortvedt [47]. Nortvedt argues that sensibility, understood as the affective part of moral sensitivity, has significance for the health care workers' moral motivation and clinical understanding: "To be emotionally affected by the expressions of illness, of bodily weakness and pain, opens up for a medical gaze that both can capture clinical signs of pathology while at the same time being able to care for the human condition of the patient and sick individual," he argues (p. 218).
} 
adequate moral theoretical approach may well involve an integration of the justice and care orientations so as to retain their respective strengths through rehabilitated notions of 'justice' and 'care", [9].

The fourth difficulty relates to the previous objection and concerns the possible tendency of an ethics of care to allow favouritism. "It would require a saint to care for some really disgusting patients," says Curzer [12], referring to a claim that it is not possible to care equally for all patients. This is one of the reasons I consider Ribes's article (2009) to be both interesting and relevant. There has been an understanding among doctors that self-injuring patients are difficult, demanding and manipulative $[6,43]$. At the same time, recent research has found that good care from doctors and health personnel is important for these patients to recover [43]. So, how do we manage to care for "difficult" and "demanding" patients? I do not have a simple answer to this question. Yet, I consider Martinsen's understanding of care as being able "to see and express the [patient's] appeal for help," involving an emotional awareness and a relational and a practical competence to represent a more feasible approach to the problem than an understanding of care, meaning to "have a liking for," which involves emotional attachment. The latter refers to the understanding of care that Curzer refers and criticizes in his article [12]. Following Martinsen, the important task is not whether we like the patient or whether we feel attached to the patient as a friend, but whether we are able to see, or become aware of the person's suffering and express it independent of his or her sympathetic or unsympathetic traits.

Burnout on the part of the physician also is identified as a possible drawback to caring in medicine. A usual way of approaching this issue in medicine has been to argue in favour of a detached model of care in which the physician remains professional, i.e., cool and undisturbed by the patient's situation. On the contrary, the American physician and philosopher Jodi Halpern argues convincingly against such an ideal of detachment in medicine, pointing to empirical studies indicating an increased risk of burnout in relation to a medical practice characterized by detachment, as well as pointing out how an empathic communication with patients "makes being a physician more meaningful and satisfying" [15, 16]. Kari Martinsen also has been criticized in a similar manner for pursuing an altruistic concept of care, allowing for self-sacrifice on the part of the health care professional $[18,50]$. I do not agree that Martinsen's care perspective is altruistic in the sense that it implies self-sacrifice. As I see it, these critics make their claim without taking into consideration the consciousness of limit inherent in the professional reflection that Martinsen emphasizes in relation to practical care work.

\section{Conclusion}

In this paper I have argued that the development of a sensous and perceiving gaze is important in medicine in order to facilitate care and refine clinical proficiency. Relying on the care philosophy of Kari Martinsen, I suggest that an understanding of care as being able "to see and express the [patient's] appeal for help" may represent a fruitful way of dealing with care in medicine. By this, both the importance of 
attentiveness as conceptualized by the perceiving eye, as well as the relational and practical dimension of care, are emphasized. Such an approach may further contribute to protecting the integrity of patients, in addition to contributing to refining the clinical abilities of physicians in the clinical encounter. Possible problems have been addressed, while some questions are also left open for further inquiry: For instance, how do we train and educate physicians in this way of seeing in medicine?

Acknowledgments This article is part of a PhD project funded by the Research Council of Norway. I am grateful for the valuable comments of Jan Helge Solbakk and Bjørn Hofmann. I also thank the two anonymous reviewers for their helpful comments.

Open Access This article is distributed under the terms of the Creative Commons Attribution Noncommercial License which permits any noncommercial use, distribution, and reproduction in any medium, provided the original author(s) and source are credited.

\section{References}

1. Agledahl, K. M., Førde, R., \& Wifstad, Aa. (2010). Clinical essentialising: A qualitative study of doctors' medical and moral practice. Medicine, Health Care and Philosophy, 13(2), 107-113.

2. Allmark, P. (1995). Can there be an ethics of care? Journal of Medical Ethics, 21, 19-24.

3. Alvsvåg, H. (2006). Philosophy of caring. In A. M. Tomey \& M. R. Alligood (Eds.), Nursing theorists and their work (pp. 167-190). St. Louis: Mosby.

4. Balint, M. (2000). The doctor, his patient and the illness. Edinburgh: Churchill Livingstone. First edition 1957.

5. Beauchamp, T. L., \& Childress, J. F. (2009). Principles of biomedical ethics (6th ed.). New York: Oxford University Press.

6. Bloch Thorsen, G. R. (2006). Selvskade og selvmord ... ingen selvfølge [Self inflicted harm and suicide ... no matter of course]. Suicidologi [Suicidology], 11(1), 5-9.

7. Bradshaw, A. (1996). Yes! There is an ethics of care: an answer for Peter Allmark. Journal of Medical Ethics, 22, 8-12.

8. Branch, W. T. (2000). The ethics of caring and medical education. Academic Medicine, 75(2), 127-132.

9. Carse, A. L. (1991). The 'voice of care': Implications for bioethical education. The Journal of Medicine and Philosophy, 16, 5-28.

10. Cates, D. F., \& Lauritzen, P. (Eds.). (2001). Medicine and the ethics of care. Washington, DC: Georgetown University Press.

11. Cluff L. E., \& Binstock R. H. (Eds.). (2001). The lost art of caring. A challenge to health professionals, families, communities, and society. Baltimore, Maryland: The Johns Hopkins University Press.

12. Curzer, H. J. (1993). Is care a virtue for health care professionals? The Journal of Medicine and Philosophy, 18, 51-69.

13. Epstein, O., Perkin, G. D., Cookson, J., Watt, I. S., Rakhit, R., Robins, A. W., et al. (2008). Clinical examination. Philadelphia: Mosby Elsevier.

14. Foucault, M. (2003). The birth of the clinic: an archaeology of medical perception. London: Routledge. First edition 1963.

15. Halpern, J. (2001). From detached concern to empathy. Humanizing medical practice. New York: Oxford University Press.

16. Halpern, J. (2003). What is clinical empathy? Journal of General Internal Medicine, 18(8), 670-674.

17. Heggen, K. (2000). Romantisering av sykepleiefaget [Romanticizing the field of nursing]. Sykepleien [Nursing] 1, 48-50. 
18. Hem, M. H. (2008). Mature care? An empirical study of interaction between psychotic patients and psychiatric nurses. Oslo: University of Oslo, unpublished thesis.

19. Holm, S. (1997). Ethical problems in clinical practice. The ethical reasoning of health care professionals. Manchester, New York: Manchester University Press.

20. Holm, S. (2001). The phenomenological ethics of K.E. Løgstrup - a resource for health care ethics and philosophy? Nursing Philosophy, 2, 26-33.

21. Holm, S. (2006). What should other health care professions learn from nursing ethics. Nursing Philosophy, 7, 165-174.

22. Johannisson, K. (1990). Medicinens öga [The eye of medicine]. Stockholm: Norstedts.

23. Kemp, P. (2000). Four ethical principles in biolaw. In P. Kemp, J. Rendtorff, \& N. M. Johansen (Eds.), Bioethics and biolaw, Vol. II. Four ethical principles (pp. 13-22). Copenhagen: Rhodos International Science and Art Publishers \& Centre for Ethics and Law.

24. Kemp, P., \& Kemp, M. L. (1998). Et liv der ikke dør: En bog om lagekunst og menneskelighet [A life that does not die: A book on the art of medicine and humanity]. Copenhagen: Spektrum.

25. Kleinman, A., \& van der Geest, S. (2009). 'Care' in health care. Remaking the moral world of medicine. Medische Antropologie, 21(1), 159-168.

26. Lazare, Aa. (1987). Shame and humiliation in the medical encounter. Archives of Internal Medicine, 147, 1653-1658.

27. Leininger, M. L. (1980). Caring: A central focus of nursing and health care services. Nursing and Health Care, 1(3), 135-143, 176.

28. Leininger, M. L. (Ed.). (1988). Care-the essence of nursing and health. Detroit: Wayne State University Press.

29. Løgstrup, K. E. (1956). Den etiske fordring [The ethical demand]. Copenhagen: Gyldendal.

30. Løgstrup, K. E. (1982). System og symbol [System and symbol]. Copenhagen: Gyldendal.

31. Løgstrup, K. E. (1995). Skabelse og tilintetgjørelse [Creation and annihilation]. Copenhagen: Gyldendal.

32. Mackenzie, G. M. (1997). The caring doctor is an oxymoron. British Medical Journal, 315, 687-688.

33. Malterud, K., \& Hollnagel, H. (2007). Avoiding humiliations in the clinical encounter. Scandinavian Journal of Primary Health Care, 25, 69-74.

34. Malterud, K., \& Hollnagel, H. (2007). Family medicine should shift attention from rationality to emotions: Affirmative position. In S. A. Buetow \& T. W. Kenealy (Eds.), Ideological debates in family medicine (pp. 165-172). New York: Nova Science Publishers.

35. Malterud, K., \& Thesen, J. (2008). When the helper humiliates the patient: A qualitative study about unintended intimidations. Scandinavian Journal of Public Health, 36(1), 92-98.

36. Martinsen, K. (1991). Omsorg og makt, ord og kropp i sykepleien [Care and power, words and body in nursing]. Sykepleien [Nursing] 2, 2-11, 29.

37. Martinsen, K. (1993). Livsmot og lidelse-den omtenksomme sykepleiers utfordring [Courage to live and suffering-challenges of the considerate nurse]. In K. Martinsen (Ed.), Den omtenksomme sykepleier [The considerate nurse] (pp. 9-16). Oslo: Tano.

38. Martinsen, K. (2003a). Omsorg, sykepleie og medisin [Care, nursing, and medicine]. Oslo: Universitetsforlaget. First edition 1989.

39. Martinsen, K. (2003b). Fra Marx til Løgstrup [From Marx to Løgstrup]. Oslo: Universitetsforlaget. First edition 1993.

40. Martinsen, K. (2003c). Fenomenologi og omsorg. Tre dialoger [Phenomenology and care. Three dialogues]. Oslo: Universitetsforlaget. First edition 1996.

41. Martinsen, K. (2006). Care and vulnerability. Oslo: Akribe.

42. McCabe, M. S. (2008). In defence of ethically caring physicians. Communication \& Medicine, 5(1), 15-24.

43. Mehlum, L., \& Holseth, K. (2009). Selvskading - hva gjør vi? [Self-harm-what approach should we take?]. Tidsskrift for Den norske legeforening [The Journal of the Norwegian Medical Association], 129(8), 759-762.

44. Meland, E., Schei, E., \& Bærheim, A. (2000). Pasientsentrert medisin—en oversikt med vekt på bakgrunn og dokumentasjon [Patient centered medicine: a review with emphasis on background and documentation]. Tidsskrift for Den norske legeforening [The Journal of the Norwegian Medical Association], 120(19), 2253-2256.

45. Nelson, H. L. (1992). Against caring. The Journal of Clinical Ethics, 3(1), 8-15.

46. Nortvedt, P. (2000). Vitenskap, sansning og fenomenologi [Science, perception and phenomenology]. Norsk tidsskrift for sykepleieforskning [Journal of Norwegian nursing research], 1, 19-36. 
47. Nortvedt, P. (2008). Sensibility and clinical understanding. Medicine, Health Care and Philosophy, 11(2), 209-219.

48. Norwegian Codes of Ethics for Doctors. (2002). The Norwegian Medical Association.

49. Olsvold, N. (2000). Omsorg er ikke bare for sykepleiere! [Care is not only for nurses!] Sykepleien [Nursing], 88(9), 62-64.

50. Pettersen, T. (2008). Comprehending care. Problems and possibilities in the ethics of care. Plymouth, UK: Lexington Books.

51. Reich, W. T. (1995). History of the notion of care. In W. T. Reich (Ed.), Encyclopedia of bioethics (pp. 319-331). New York: Simon \& Schuster Macmillan.

52. Reich, W. T. (1995). Historical dimensions of an ethic of care in health care. In W. T. Reich (Ed.), Encyclopedia of bioethics (pp. 331-336). New York: Simon \& Schuster Macmillan.

53. Ribe, K. (2009). Legen som skalv på hendene mens han sydde [The doctor whose hands trembled while he was suturing]. Tidsskrift for Den norske legeforening [The Journal of the Norwegian Medical Association], 129(8), 780.

54. Stortingsmelding, nr. 26 [Report to the Norwegian Parliament, no 26]. (1999-2000). Om verdiar for den norske helsetenesta [On values in the Norwegian health care system]. Det Kongelige Sosial- og Helsedepartement [The Royal Department of Social Security and Health].

55. The Bible. (1994). Gospel of Luke (Vol. 33). Oslo: The Norwegian Bible Company, Ch. 10.

56. Tong, R. (1998). The ethics of care: A feminist virtue ethics of care for healthcare practitioners. Journal of Medicine and Philosophy, 23(2), 131-152.

57. Tronto, J. (1993). Moral boundaries. A political argument for an ethic of care. New York, London: Routledge.

58. Weiner, S. J., \& Auster, S. (2007). From empathy to caring: Defining the ideal approach to a healing relationship. Yale Journal of Biology and Medicine, 80, 123-130. 